\title{
Malignant Exocrine Pancreas Neoplasm
}

National Cancer Institute

\section{Source}

National Cancer Institute. Malignant Exocrine Pancreas Neoplasm. NCI Thesaurus. Code C7430.

A malignant neoplasm that arises from the epithelial cells of the exocrine pancreatic tissue. 